\title{
First report of Trichinella spiralis from the white-eared (Didelphis albiventris) and the thick-tailed opossum (Lutreolina crassicaudata) in central Argentina
}

\author{
R. CASTAÑO ZUBIETA ${ }^{1}$, M. RUIZ ${ }^{1}$, G. MORICI ${ }^{1}$, R. LOVERA ${ }^{2}$, M. S. FERNÁNDEZ ${ }^{3}$, \\ J. CARACOSTANTOGOLO ${ }^{1}$, R. CAVIA ${ }^{2 *}$
}

\begin{abstract}
${ }^{1}$ Instituto Nacional de Tecnología Agropecuaria (INTA Castelar). Instituto de Patobiología, CICVyA, Area de Parasitología; ${ }^{2}$ Departamento de Ecología, Genética y Evolución, Facultad de Ciencias Exactas y Naturales, Universidad de Buenos Aires and Instituto de Ecología, Genética y Evolución de Buenos Aires (IEGEBA),

UBA-CONICET, ${ }^{*}$ E-mail: rcavia@ege.fcen.uba.ar; ${ }^{3}$ Centro Nacional de Diagnóstico e Investigación en Endemo-Epidemias ANLIS, Ministerio de Salud de la Nación and Consejo Nacional de Investigaciones Científicas y Técnicas (CONICET)
\end{abstract}

\begin{abstract}
Summary
Trichinellosis is a zoonotic disease caused by nematodes of the genus Trichinella. Humans, who are the final hosts, acquire the infection by eating raw or undercooked meat of different animal origin. Trichinella spiralis is an encapsulated species that infects mammals and is widely distributed in different continents. In Argentina, this parasite has been reported in the domestic cycle that includes pigs and synanthropic hosts (mainly rats and some carnivores). This is the first report of T. spiralis in the opossums Didelphis albiventris and Lutreolina crassicaudata in Argentina, and the first report in opossums in South America. In this survey, Trichinella larvae were detected by enzymatic digestion in three $D$. albiventris and one $L$. crassicaudata captured on pig and dairy farms located in the northeast of Buenos Aires province. The microscopic examination of the 32 larvae isolated presented the diagnostic characteristic of the genus Trichinella. Two larvae isolated from two $D$. albiventris and one from $L$. crassicaudata were identified as T. spiralis by nested multiplex PCR and confirmed by sequencing. Further research to determine the burdens of $T$. spiralis in opossums may contribute to a better understanding of the risk of $T$. spiralis transmission to the synanthropic populations.
\end{abstract}

Keywords: Trichinella spiralis; opossum; Didelphis albiventris; Lutreolina crassicaudata; Argentina

\section{Introduction}

Trichinellosis, the zoonotic disease also known as trichinosis or trichiniasis, is caused by nematodes belonging to the genus Trichinella (Murrell, 2007). The occurrence of trichinellosis in humans is strictly related to cultural food practices, including the consumption of raw or undercooked meat of different animal origin. Trichinella spp. infection has been documented in both domestic (mainly pigs) and wild animals (Pozio, 2007). T. spiralis, widely distributed in different continents (Pozio, 2005), is the species involved in the domestic cycle that includes pigs and synanthropic hosts (like rats, marsupials and some carnivores). Humans accidentally acquire the infection by eating raw meat of infected pigs.

In Argentina, according to the current legislation, all slaughtered pigs in pork meat industries are subjected to HCl-pepsin digestion to avoid human infection. Nevertheless, pigs raised for own consumption and wild animals are not included in this legislation and are not controlled, thus representing the most important source of human infection. As a result, 5700 human cases have been reported in the last ten years (Bolpe, 2011). It has been proposed that the outdoor rearing of pigs is a major risk of transmission of $T$. spiralis because of the increased exposure to sylvatic and synanthropic hosts (mainly rats and some carnivores). $T$. spiralis can also be transmitted from pigs to synanthropic and sylvatic animals (Leiby et al., 1990).

Trichinella spp. from sylvatic cycles have also caused human outbreaks as a result of the consumption of meat from puma (Puma concolor), armadillo (Chaetophractus villusus) and wild boar (Sus scrofa) (Ribicich et al., 2005). This parasite has also been detected in foxes (Pseudalopex gracilis) (Minoprio et al., 1967). The recent description of the new species T. patagoniensis isolated from the puma in the Argentine Patagonia (Krivokapich et al., 2012) makes it necessary to find out which wild animals are infected by each of these two Trichinella species as well as which are the areas of influence of the two parasites.

Marsupials are found in many different environments, from forests to domestic and peridomestic habitats like orchards, henhouses and poultry farms (Cabrera \& Yepes, 1960; Hunsaker II, 1977; Contreras, 1983; Gómez Villa- 
fañe et al., 2004). Since they have been described as reservoirs of numerous diseases (Potkay, 1977; Schweigmann et al., 1999; Gomes et al., 2003; Bodini Santiago et al., 2007; Pérez Carusi et al., 2009), some marsupials are considered a link between wild and domestic habitats for the transmission of zoonotic diseases (Gómez Villafañe et al., 2004; Pérez Carusi et al., 2009).

In environments related to the human population, opossums of the genus Didelphis are associated with garbage produced by humans, indicating the close relation between these animals and humans (Pérez Carusi et al., 2009). Didelphis albiventris, the white-eared opossum, is one of the six species of the genus. It is widely distributed in the American continent, from eastern North America throughout eastern South America, from northeastern Brazil through Paraguay, Uruguay and southern Argentina, up to $47^{\circ} \mathrm{S}$ (Cabrera \& Yepes, 1960; Cerqueira, 1985; Navone \& Suriano, 1992; Lemos \& Cerqueira, 2002). Although $D$. albiventris is mainly insectivorous, it may adopt omnivorous feeding habits, including fruits and vertebrates in its diet (Cabrera \& Yepes, 1960; Navone \& Suriano, 1992; Cáceres, 2002), thus appearing to be opportunistic (Aléssio et al., 2005).

Lutreolina crassicaudata, the thick-tailed opossum, which is the only living species of the genus, also has a wide distribution, occurring in southern Brazil, Argentina, Uruguay, Paraguay and part of Bolivia, as well as in areas of northern South America, such as Colombia, Venezuela and Guyana (Redford \& Eisenberg, 1992; Flores et al., 2007). Although L. crassicaudata is less studied than D. albiventris and other didelphid marsupial species (Santori et al., 2005), it is known that this marsupial has omnivorous habits (Cáceres et al., 2002; Muschetto et al., 2011). Monodelphis dimidiate, the southern short-tailed opossum, and Gracilinanus agilis, the gracile mouse opossum, are two other opossums that occur in our study area but in very low abundances.

The aim of this work is to report the first findings of Trichinella in the opossums D. albiventris and L. crassicaudata on intensive animal breeding farms in central Argentina.

\section{Materials and methods}

\section{Study area}

The fieldwork was carried out in the localities of Marcos Paz, Las Heras, Exaltación de la Cruz and San Andrés de Giles located in the northeast of Buenos Aires province, Argentina. The climate is temperate with a mean annual temperature of $17.4{ }^{\circ} \mathrm{C}$ (IGM, 1998). The original pastures have been replaced by grain crops and natural or implanted pastures for livestock breeding. The intensive poultry, porcine and bovine cattle farming is also characteristic of this rural area. Trichinellosis is the parasitary disease with highest incidence in Buenos Aires province, with 2387 human cases reported from 2000 to 2010. This is half of the total cases for all the country.
Opossum survey and larvae identification

This study was carried out on porcine and dairy farms as a part of a larger survey where the ecology and parasitology of synanthropic mammals were studied. Trapping campaigns were conducted on ten pig farms and eight dairy farms from December 2008 to November 2011. Each of these farms was sampled four times along one year (once each season). Opossums were captured using cage live traps $(15 \times 16 \times 31 \mathrm{~cm})$ set in lines in the perimeter of pig sheds or dairies, houses, machinery sheds, food storage sheds or silos and in vegetated areas (including lawn areas, stream weedy borders and weedy borders below fences). The distance between neighboring traps along the lines was 5 to $10 \mathrm{~m}$. Traps were active for three consecutive nights and baited with beef and carrot. The opossums captured were identified to species level. Animals were euthanized with an overdose of ketamine-acepromacine according to Pérez Carusi et al. (2009). The tongue, diaphragm, intercostals and leg muscles were removed and preserved at -30 to $0{ }^{\circ} \mathrm{C}$. A pool of the total muscle samples from each animal was analyzed by artificial digestion in $1 \% \mathrm{HCl}, 1 \%$ pepsin (Gamble et al., 2000). All larvae isolated were morphologically identified using an inverted microscope. Genomic DNA from all single muscle larvae was extracted and analyzed by nested-multiplex PCR according to Zarlenga et al. (1999). The expansion segment five (ESV) was amplified. Muscle larvae of the Trichinella spp. reference isolates $T$. spiralis (ISS599) and T. patagoniensis (ISS2311) were used as controls. Forward and reverse sequencing was carried out on PCR products by a capillary DNA sequencer ABI 3730xl DNA analyzer (Applied Biosystems, Macrogen Inc., Seoul, South Korea). Nucleotide sequences were aligned with published sequences for T. spiralis (Mallatt \& Winchell, 2002) using the software of the European Bioinformatics Institute website (http://www.ebi.ac.uk/Tools/clustalw2/).

\section{Results}

A total of 61 opossums (41 D. albiventris and 20 L. crassicaudata) were captured during the study period, with a total trapping effort of 7026 trap-nights. D. albiventris was captured on four dairy farms and six porcine farms, while L. crassicaudata was captured on three dairy farms and one porcine farm.

Muscle samples of a total of 59 opossums were processed (mean weight $=9.01 \mathrm{~g}$, standard deviation $=6.11 \mathrm{~g}$, minimum $=1.45 \mathrm{~g}$, maximum $=24.00 \mathrm{~g}$ ), while samples of two opossums were lost. We found 32 Trichinella spp. larvae in three $D$. albiventris (with $0.67,2.81$ and 1.36 larvae per gram), and one L. crassicaudata (with 0.26 larvae per gram). Two of the infected opossums were captured on a stream border of one dairy farm (one $D$. albiventris and the L. crassicaudata), while the other two D. albiventris were captured on a food shed of another dairy farm and on a breeding shed of a porcine farm. The examination of the 32 larvae under microscope showed the presence of the stichosome, which is a diagnostic characteristic of the genus 
Trichinella. The other morphological characteristics observed were also consistent with this genus. Additionally, one larva isolated from a $D$. albiventris could not be identified, but it did not have the typical morphological characteristics of the genus Trichinella.

The genomic DNA extraction was successful for 15 out of the 32 larvae found, and in three of these 15 the ESV was amplified successfully. Two larvae isolated from two $D$. albiventris and only one from $L$. crassicaudata were identified as $T$. spiralis by nested multiplex PCR, generating the 173-bp fragment consistent with the pattern for T. spiralis (Fig. 1). Two isolates, one from $D$. albiventris and the other from $L$. crassicaudata, were also confirmed as $T$. spiralis by sequencing. CLUSTALW2 alignments showed sequences identical to those deposited by Mallatt \& Winchell (Mallatt \& Winchell, 2002) at GenBank (accession number AF342803.1).
36 D. albiventris studied. Less is known about L. crassicaudata. In central Argentina, this species has been found parasitized by the helminths Turgida turgida, Pterygodermatites kozeki, Aspidodera raillieti, by the nematodes Mathevotaenia sp., and by the acanthocephalans Hamanniella microcephala (Navone et al., 1991). In Florianópolis, Brazil, L. crassicaudata has been found parasitized by the protozoan Tetratrichomonas didelphidis (Tasca et al., 2001).

The number of opossums captured in this study was low to estimate the prevalence in the populations. More individuals of $D$. albiventris and $L$. crassicaudata in a longer period of time should thus be analyzed to determine the role of these opossums as reservoirs or sporadic hosts of $T$. spiralis in the study area. Additional studies about the role of these opossums for pig infection with $T$. spiralis are also needed. However, the fact that we detected infected ani-

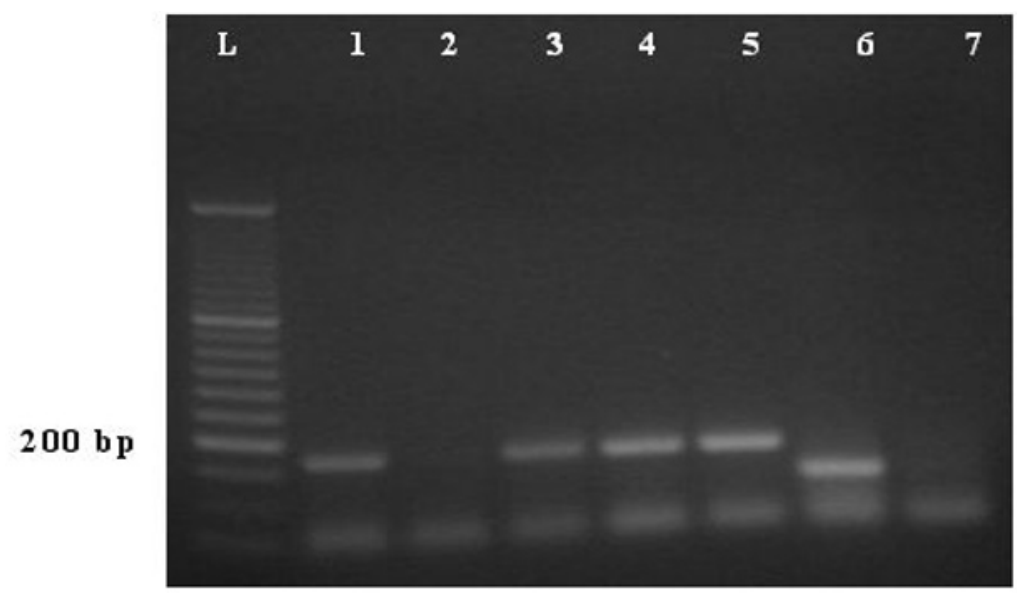

Fig. 1. Agarose gel separation of nested multiplex PCR products from: (1) single larva collected from one D. albiventris, (2) single larva collected from one $D$. albiventris that showed no features of the genus Trichinella, (3) single larva collected from another D. albiventris, (4) single larva collected from one L. crassicaudata, (5) T. spiralis reference strain (ISS599), (6) T. patagoniensis reference strain (ISS2311), (7) negative control, (L) 50-bp ladder

\section{Discussion}

Knowledge about pathogens of $L$. crassicaudata and $D$. albiventris is scarce and there are no previous reports of $T$. spiralis infection, being our findings the first report of $T$. spiralis in these species and the first report in opossums in South America. In Argentina, some studies looked for this infection in D. albiventris with negative results (Gómez Villafañe et al., 2004; Pérez Carusi et al., 2009; Ribicich et al., 2010). In contrast, in the USA, two opossums, D. marsupialis and $D$. virginiana, have been previously reported to be infected with Trichinella spp. (Pozio, 2005).

As mentioned, in Argentina, some opossums are considered a potential link between wild and domestic habitats for the transmission of zoonotic diseases (Gómez Villafañe et al., 2004; Pérez Carusi et al., 2009). Pérez Carusi et al. (2009) conducted a screening of different pathogens in $D$. albiventris in a rural area of central Argentina and found Leptospira interrogans and Salmonella enterica in $13 \%$ and $4 \%$ of the 179 individuals tested, respectively, but found no individuals infected by $T$. spiralis. Moreover, Ribicich et al. (2010) reported no Trichinella spp. in other mals suggests that these opossums could participate in the transmission cycle of $T$. spiralis. The infected opossums were all captured on pig and dairy farms and one $D$. albiventris was found inside a food storage shed of a dairy farm with high human activity. Since these opossums have home ranges that exceeded the farm limits, with moving areas around the nesting place of 7.04 ha for $D$. albiventris (Sanches Quadros Altomare et al., 2012) and 0.95 ha for $L$. crassicaudata (Cajal, 1981), they could use the surrounding rural habitats of the farms. Also, individuals of Norway rat (Rattus norvegicus), black rat ( $R$. rattus), and house mouse (Mus musculus) have been previously found infected with $T$. spiralis on the farms studied in the present survey (Lovera R, unpublished data). For all these reasons, we agree with the idea that these opossum species could act as a link between wild and domestic habitats for the transmission of zoonotic diseases as Trichinellosis.

\section{Acknowledgements}

We are extremely grateful to Ignacio, Tito, Mario, Roberto, Augusto, Santiago, Mariano, Pablo, Horacio, Lautaro, 
Hugo, Osvaldo, Nicolás, Juan Carlos, Guillermo, Juanchi, Ramón, Diego, Maxi, Miguel, managers, owners and professionals of the pig and dairy farms for their support. We also thank Violeta Rimieri, María Victoria Vadell, Daniela Montes de Oca, Vanina León, María Busch, Noelia Campallo, Emiliano Muschetto, Isabel Gómez Villafañe, Mariano Gonzalez King, Ignacio Gould and Laura Calfayán for their assistance in the fieldwork. We would also like to thank "San Marco Veterinary" for their help, hospitality and logistical support. This research was supported by grants from the Instituto Nacional de Tecnología Agropecuaria (INTA), Universidad de Buenos Aires (UBACYT), Agencia Nacional de Promoción Científica y Tecnológica and CONICET (Argentina). Handling of animals throughout the study followed Argentine Law for Animal Care (National Law 14346; see http://www.sarem.org.ar).

\section{References}

AlÉssio, F. M., Mendes Pontes, A. R., LunA DA Silva, V. (2005): Feeding by Didelphis albiventris on tree gum in the northeastern Atlantic forest of Brazil. Mastozool. Neotrop., 12(1): $37-52$

Bodini SANTIAGo, M. E., VAsconcelos, R. O., ReINALdo Fattori, K., Prado Munari, D., Michelin, A. D. F., LIMA, V. M. F. (2007): An investigation of Leishmania spp. in Didelphis spp. from urban and peri-urban areas in Bauru (São Paulo, Brazil). Vet. Parasitol., 150(4): 283 290. DOI: 10.1016/j.vetpar.2007.09.026

BOLPE, J. E. (2011): Triquinosis: aspectos epidemiológicos, de diagnóstico y control de una zoonosis endémica en la República Argentina. In: J. BASUALDO, R. CACCHIONE, R. Durlach, P. Martino, A. SeiJo (Eds.) Temas de zoonosis $V$, Asociación Argentina de Zoonosis, Buenos Aires, pp. $347-354$

CABRERA, A., YePES, J. (1960): Mamíferos Sud-Americanos. $2^{\text {nd }}$ Edition. Buenos Aires, Argentina: Companía Argentina de Editores SA, $347 \mathrm{pp}$.

CÁCERES, N. C. (2002): Food habits and seed dispersal by the white-eared opossum, Didelphis albiventris, in southern Brazil. Stud. Neotrop. Fauna Env., 37(2): 97 - 104. DOI: $10.1076 /$ snfe.37.2.97.8582

CÁCeres, N. C., Ghizoni-Jr, I., Graipel, M. (2002): Diet of two marsupials, Lutreolina crassicaudata and Micoureus demerarae, in a coastal Atlantic Forest island of Brazil. Mammalia, 66(3): 331 - 340. DOI: 10.1515/mamm. 2002.66.3.331

CAJAL, J. (1981): Estudios preliminares sobre el área de acción en marsupiales (Mammalia, Marsupialia). Physis $C$, 40: $27-37$

CerqueIRA, R. (1985): The distribution of Didelphis in South America (Polyprotodontia, Didelphidae). J. Biogeogr., 12(2): 135 - 145. DOI: 10.2307/2844837

Contreras, J. (1983): La comadreja overa. In: J. Contreras (Ed) Fauna Argentina. Buenos Aires, Argentina: Centro Editor de América Latina, pp. 1 - 32

Flores, D., Díaz, M., BArquez, R., Kelt, D., Lessa, E., SAlazAr-Bravo, J., PATton, J. (2007): Systematics and
Distribution of Marsupials in Argentina: a review. In: Kelt, D. A., Lessa, E. P., SAlazar-Bravo, J., Patton, J. L. (Eds) The Quintessential Naturalist. Honoring the Life and Legacy of Oliver P. Pearson. Berkeley, USA: University of California Publications in Zoology, pp. 579 - 670

Gamble, H., Bessonov, A., Cuperlovic, K., GajadHar, A., Van Knapen, F., Noeckler, K., Schenone, H., Zhu, X. (2000): International Commission on Trichinellosis: Recommendations on methods for the control of Trichinella in domestic and wild animals intended for human consumption. Vet. Parasitol., 93(3): 393 - 408. DOI: 10.1016/S0304-4017(00)00354-X

Gomes, D. C., Cruz, R. P. D., Vicente, J. J., Pinto, R. M. (2003): Nematode parasites of marsupials and small rodents from the Brazilian Atlantic Forest in the State of Rio de Janeiro, Brazil. Rev. Bras. Zool., 20(4): 699 - 707. DOI: 10.1590/S0101-81752003000400024

Gómez Villafañe, I. E., MiÑarro, F., Ribichich, A. M., Rossetti, C. A., Rossotti, D., Busch, M. (2004): Assessment of the risks of rats (Rattus norvegicus) and opossums (Didelphis albiventris) in different poultry-rearing areas in Argentina. Braz. J. Microbiol., 35: 359 - 363. DOI: $10.1590 / \mathrm{S} 1517-83822004000300017$

IGM (1998): Atlas Geográfico de la República Argentina. Buenos Aires, Argentina: Instituto Geográfico Militar, 95 pp.

HUNSAKER II, D. (1977): Ecology of New World marsupials. In: HUNSAKER II, D. (Ed) The biology of marsupials. New York, USA: Academic Press, pp. $99-113$

Krivokapich, S. J., Pozio, E., Gatti, G. M., Gonzalez Prous, C. L., Ribicich, M., Marucci, G., RosA, G. L., CONFAlONIERI, V. (2012): Trichinella patagoniensis n. sp. (Nematoda), a new encapsulated species infecting carnivorous mammals in South America. Int. J. Parasitol., 42(10): 903 - 910. DOI: 10.1016/j.ijpara.2012.07.009

Leiby, D. A., Duffy, C. H., Murrell, K. D., Schad, G. A. (1990): Trichinella spiralis in an agricultural ecosystem: transmission in the rat population. J. Parasitol., 76: $360-$ 364. DOI: $10.1007 / \mathrm{BF} 00536342$

Lemos, B., CERQueIRA, R. (2002): Morphological differentiation in the white-eared opossum group (Didelphidae: Didelphis). J. Mammal., 83(2): 354 - 369. DOI: 10.1644/1545-1542(2002)083<0354:MDITWE > 2.0.CO;2

Mallatt, J., Winchell, C. J. (2002): Testing the new animal phylogeny: first use of combined large-subunit and small-subunit rRNA gene sequences to classify the protostomes. Mol. Biol. Evol., 19(3): 289 - 301. DOI: 10.1093/oxfordjournals.molbev.a004082

Minoprio, J., NAVES, H., ABdon, D. (1967): Factores ecológicos determinantes de la triquinosis silvestre en el oeste de San Luis y este de Mendoza. Anales Soc. Cientif. Arg. 183: $19-30$

MURRELL, K. (2007): Trichinellosis: The global status and essentials for control. In: C. EDDI, M. VARGAS TERÁN (Eds.) Mejoramiento del control de la trichinellosis. Rome, Italy: FAO America Latina y el Caribe, pp. $100-111$ Muschetto, E., Cueto, G. R., SuÁrez, O. V. (2011): New data on the natural history and morphometrics of Lutre- 
olina crassicaudata (Didelphimorphia) from central-eastern Argentina. Mastozool. Neotrop., 18(1): 73 - 79

NAVONE, G. T., SuRIANO, D. M. (1992): Species composition and seasonal dynamics of the helminth community parasitizing Didelphis albiventris (Marsupialia: didelphidae) in savannas of the central Argentina. Ecol. Austral., 2(2): 95 - 100

Navone, G. T., Suriano, D. M., Pujol, C. A. (1991): Travassostrongylus yungaensis $\mathrm{n}$. $\mathrm{sp}$. and Hoineffia simplicispicula n. sp. (Nematoda: Trichostrongyloidea) from Thylamys venustus cinderellus and Lutreolina crassicaudata (Marsupialia: Didelphidae) in the northwest of Argentina. Syst. Parasitol., 19(3): 187 - 193. DOI: 10.1007/BF00011886

Pérez Carusi, L. C., Farace, M. I., Ribicich, M. M., GÓMEZ VILlafAÑE, I. E. (2009): Reproduction and parasitology of Didelphis albiventris (Didelphimorphia) in an agroecosystem landscape in central Argentina. Mammalia, 73(2): 89 - 97. DOI: 10.1515/MAMM.2009.033

POTKAY, S. (1977): Diseases of marsupials. In: HUNSAKER II, D. (Ed) The biology of marsupials. New York, USA: Academic Press, pp. 415 - 506

PozIO, E. (2005): The broad spectrum of Trichinella hosts: from cold-to warm-blooded animals. Vet. Parasitol., 132(1 - 2): 3 - 11. DOI: 10.1016/j.vetpar.2005.05.024

PozIO, E. (2007): World distribution of Trichinella spp. infections in animals and humans. Vet. Parasitol., 149(1 2): 3 - 21. DOI: 10.1016/j.vetpar.2007.07.002

REDFORD, K. H., EISENBERG, J. F. (1992): Mammals of the Neotropics, Volume 2: The Southern Cone: Chile, Argentina, Uruguay, Paraguay (Vol. 2). Chicago, USA: University of Chicago Press, 435 pp.

Ribicich, M., Gamble, H. R., Bolpe, J., Scialfa, E., Krivokapich, S., Cardillo, N., Betti, A., Cambiaggi Holzmann, M. L., PAsqualetti, M., FARIÑA, F. (2010):
Trichinella infection in wild animals from endemic regions of Argentina. Parasitol. Res., 107: 377 - 380. DOI: 10.1007/s00436-010-1873-3

Ribicich, M., Gamble, H. R., Rosa, A., Bolpe, J., FrANCO, A. (2005): Trichinellosis in Argentina: an historical review. Vet. Parasitol., 132(1 - 2): 137 - 142. DOI: 10.1016/j.vetpar.2005.05.042

Sanches Quadros Altomare, V., Menezes de ArRuda Gomes, M., De Camargo Passos, F., Graciolli, G., DE AQuino RiBAS, A. C. (2012): Home-range and space use by Didelphis albiventris (Lund 1840) (Marsupialia, Didelphidae) in Mutum Island, Paraná river, Brazil. Biota Neotrop., 12(4): 50 - 55. DOI: 10.1590/S1676-06032012000 400004

SANTORI, R. T., Rocha-Barbosa, O., Vieira, M. V., MAgnAn-Neto, J. A., Loguercio, M. F. (2005): Locomotion in aquatic, terrestrial, and arboreal habitat of thicktailed opossum, Lutreolina crassicaudata (Desmarest, 1804). J. Mammal., 86(5): 902 - 908. DOI: 10.1644/15451542(2005)86[902:LIATAA]2.0.CO;2

Schweigmann, N. J., Pietrokovsky, S., Bottazzi, V., Conti, O., Bujas, M. A., Wisnivesky-Colli, C. (1999): Study of the prevalence of infection by Trypanosoma cruzi in opossums (Didelphis albiventris) in Santiago del Estero, Argentina. Rev. Panam. Salud Púb., 6(6): 371 - 377. DOI: 10.1590/S1020-49891999001100001

TAsca, T., De CARli, G. A., Glock, L., JeCKel-Neto, E. A. (2001): Morphologic aspects of Tetratrichomonas didelphidis isolated from opossums Didelphis marsupialis and Lutreolina crassicaudata. Mem. Inst. Oswaldo Cruz, 96(2): 265 - 271. DOI: 10.1590/S0074-02762001000200022 Zarlenga, D. S., Chute, M. B., Martin, A., Kapel, C. M. (1999): A multiplex PCR for unequivocal differentiation of all encapsulated and non-encapsulated genotypes of Trichinella. Int. J. Parasitol., 29(11): 1859 - 1867. DOI: 10.1016/S0020-7519(99)00107-1 